\title{
SCT Gene Product
}

National Cancer Institute

\section{Source}

National Cancer Institute. SCT Gene Product. NCI Thesaurus. Code C148312.

A protein encoded by the SCT gene. 